\title{
Streptomyces hypolithicus sp. nov., isolated from an Antarctic hypolith community
}

\author{
Correspondence \\ Stephanie G. Burton \\ BurtonS@cput.ac.za
}

\author{
Marilize Le Roes-Hill, ${ }^{1}$ † Jeffrey Rohland, ${ }^{2}$ Paul R. Meyers, ${ }^{2}$ Don A. Cowan ${ }^{3}$ \\ and Stephanie G. Burton ${ }^{1} \dagger$
${ }^{1}$ Department of Chemical Engineering, University of Cape Town, Private Bag X3, Rondebosch, 7701 Cape Town, South Africa
${ }^{2}$ Department of Molecular and Cell Biology, University of Cape Town, Private Bag X3, Rondebosch, 7701 Cape Town, South Africa
${ }^{3}$ Institute for Microbial Biotechnology and Metagenomics, Department of Biotechnology, University of the Western Cape, Bellville, 7535 Cape Town, South Africa

\begin{abstract}
As part of an enzyme-screening programme, an actinobacterium, strain $\mathrm{HSM}^{\prime} 10^{\top}$, was isolated from a sample collected from the base of a translucent quartz rock in Miers Valley, eastern Antarctica. The isolate produced branching vegetative mycelium that was characteristic of filamentous actinobacteria. The chemotaxonomic characteristics of the strain suggested that $\mathrm{HSM} \# 10^{\top}$ should be classified as a member of the genus Streptomyces. Furthermore, phylogenetic analysis based on 16S rRNA gene sequences showed that the strain was closely related to members of the genus Streptomyces, which supports the classification of this strain within the family Streptomycetaceae. Phenotypic and phylogenetic results allowed strain $\mathrm{HSM} \# 10^{\top}$ to be differentiated from known streptomycetes. DNA-DNA hybridization data also showed that strain $\mathrm{HSM} \# 10^{\top}$ could be differentiated from its nearest phylogenetic neighbours Streptomyces chryseus DSM 40420 ${ }^{\top}$ (53.55 $\pm 3.15 \%$ DNA relatedness), Streptomyces helvaticus DSM $40431^{\top}(38.75 \pm 2.75 \%)$, Streptomyces flavidovirens DSM $40150^{\top}$ $(30.7 \pm 2.90 \%)$ and Streptomyces albidochromogenes DSM $41800^{\top}(33.9 \pm 0.10 \%)$. Therefore, the name Streptomyces hypolithicus sp. nov. is proposed, with $\mathrm{HSM}_{10} 0^{\top}$ (=DSM $41950^{\top}$ $=$ NRRL B-24669 ${ }^{\mathrm{T}}$ ) as the type strain.
\end{abstract}

A hypolith can be defined as an organism that inhabits the microenvironment located under translucent quartz rocks (hypolithons) in either cold or hot deserts. Such rocks typically provide protection from direct sunlight, serve as a refuge against physical (aolian) disturbance and trap moisture as a source of water. Most hypoliths are photosynthetic micro-organisms belonging to the cyanobacteria (Cockell \& Stokes, 2004). The unique microenvironments under translucent quartz rocks serve as a rich source of potentially novel microbes and, hence, potentially novel biocatalysts that can be used in biotransformation reactions that require extreme conditions (Thomas, 2005).

tPresent address: Biocatalysis and Technical Biology Research Group, Cape Peninsula University of Technology, Bellville Campus, PO Box 1906, Bellville, 7535 Cape Town, South Africa.

The GenBank/EMBL/DDBJ accession number for the 16S rRNA gene sequence of strain $\mathrm{HSM} \# 10^{\top}$ is EU196762.

Growth characteristics of strain $\mathrm{HSM} \# 10^{\top}$ and closely related strains on different agar media are available as supplementary material with the online version of this paper.
As part of a screening programme for oxidative enzymeproducing actinobacteria, a novel actinobacterium was isolated from samples collected from the base of translucent quartz rocks in Miers Valley in the McMurdo Dry Valleys region of eastern Antarctica.

Hypolithic community samples were collected by one of us (D.A.C.) from around the base of translucent quartz rocks. Samples were stored below $0{ }^{\circ} \mathrm{C}$, transported on dry ice and stored at $-80{ }^{\circ} \mathrm{C}$ until processed.

Strain HSM\#10 ${ }^{\mathrm{T}}$ was isolated on starch-casein-nitrate agar (Atlas, 2004) using a standard soil isolation technique: $0.1 \mathrm{~g}$ sample was suspended in $1 \mathrm{ml}$ sterile distilled water and the mixture was vortexed for $5 \mathrm{~min}$ and allowed to settle for $1 \mathrm{~min}$. A 100-fold dilution of the suspension was plated in triplicate. Strain $\mathrm{HSM} \# 10^{\mathrm{T}}$ was isolated after incubation at room temperature $\left(22^{\circ} \mathrm{C}\right)$ for 21 days. Following isolation, strain $\mathrm{HSM} \# 10^{\mathrm{T}}$ was maintained on International Streptomyces Project medium 7 agar (ISP 7; Shirling \& Gottlieb, 1966).

The morphological characteristics of strain HSM\#10 ${ }^{\mathrm{T}}$ were determined using standard methods (Locci, 1989). The 
isolate was grown on ISP 4 agar (Shirling \& Gottlieb, 1966) for 21 days at $22{ }^{\circ} \mathrm{C}$ and morphology was observed under a light microscope and by scanning electron microscopy. Growth characteristics of HSM $\# 10^{\mathrm{T}}$ were also observed on Czapek solution agar (Atlas, 2004) and Middlebrook 7H9 agar (Becton Dickinson; supplemented with $10 \mathrm{mM}$ glucose and with the ADC enrichment omitted) and compared with those of its closest phylogenetic neighbours.

Standard physiological tests were performed as described by Locci (1989). ISP media were prepared as described by Shirling \& Gottlieb (1966). Antibiotic resistance was determined by incorporation of antibiotics into Bennett's medium agar plates (Atlas, 2004) at the recommended concentrations (Locci, 1989). Physiological characteristics were determined after growth at $22{ }^{\circ} \mathrm{C}$ (unless otherwise stated) for the recommended incubation periods. All carbon sources for carbon utilization tests were filtersterilized and tested at the concentrations recommended by Locci (1989) and Shirling \& Gottlieb (1966). Staining was performed using the standard Gram staining technique.

Freeze-dried cells used in chemotaxonomic tests were obtained from a $500 \mathrm{ml}$ ISP 2 culture of strain $\mathrm{HSM} \# 10^{\mathrm{T}}$, which was cultivated on an orbital shaker at $22{ }^{\circ} \mathrm{C}$ for 14 days. The diaminopimelic acid isomer and whole-cell sugar pattern were determined as described by Hasegawa et al. (1983) except that freeze-dried cells were used instead of colonies from agar plates.

The 16S rRNA gene was amplified by PCR using the bacterial 16S rRNA gene primers F1 and R5 (Cook \& Meyers, 2003). PCR conditions were as described by Cook \& Meyers (2003). The amplified DNA was purified for sequencing using a MSB Spin PCRapace PCR purification kit (Invitek). For phylogenetic analysis, reference strains chosen from BLAST results (Altschul et al., 1997), as well as type strains from other genera within the family Streptomycetaceae, were used. The top hits from the identity analysis of the EzTaxon server (Chun et al., 2007) were also included. For the construction of phylogenetic trees, the software package MEGA version 3.1 (Kumar et al., 2004; http://www.megasoftware.net/) was used. Unrooted phylogenetic trees were constructed using the neighbour-joining (Saitou \& Nei, 1987), minimum evolution and maximum-parsimony methods (Takahashi \& Nei, 2000) and evaluated by bootstrap resampling (1000 replications).

DNA-DNA hybridization was performed between strain HSM $\# 10^{\mathrm{T}}$ and the following strains: Streptomyces chryseus DSM $40420^{\mathrm{T}}$, Streptomyces helvaticus DSM $40431^{\mathrm{T}}$, Streptomyces flavidovirens DSM $40150^{\mathrm{T}}$ and Streptomyces albidochromogenes DSM $41800^{\mathrm{T}}$. Analysis was performed by the Identification Service of the Deutsche Sammlung von Mikroorganismen und Zellkulturen $\mathrm{GmbH}$ (Braunschweig, Germany). DNA was isolated using a French pressure cell (Thermo Spectronic) and purified by chromatography on hydroxyapatite as described by Cashion et al. (1977). DNA-DNA hybridization was carried out as described by De Ley et al. (1970) [incorporating the modifications described by $\mathrm{Huß}$ et al. (1983)] using a Cary 100 Bio UV/VIS-spectrophotometer equipped with a Peltier-thermostatted $6 \times 6$ multicell changer and a temperature controller with in situ temperature probe (Varian).

From scanning electron microscopy (Fig. 1), it is evident that the strain produces smooth spores with straight chain morphology. Light microscopy analysis showed that growth appeared branched with Rectiflexibiles-type spore chain morphology.

Chemotaxonomic characteristics of strain $\mathrm{HSM} \# 10^{\mathrm{T}}$ suggest that this strain should be classified as a member of the genus Streptomyces. LL-Diaminopimelic acid was detected in its peptidoglycan and whole-cell hydrolysates yielded no diagnostic sugars (Lechevalier \& Lechevalier, 1970).

A 1499 bp 16S rRNA gene sequence was obtained for strain HSM $\# 10^{T}$. A BLAST search revealed similarities of $98.1 \%$ to S. chryseus NBRC $13377^{\mathrm{T}}$ and S. helvaticus NBRC $13382^{\mathrm{T}}$ and $97.7 \%$ to $S$. albidochromogenes NBRC $101003^{\mathrm{T}}$ and $S$. flavidovirens NBRC $13039^{\mathrm{T}}$. These values are low enough to suggest that strain $\mathrm{HSM} \# 10^{\mathrm{T}}$ represents a distinct species (Keswani \& Whitman, 2001; Stackebrandt \& Ebers, 2006). Furthermore, DNA-DNA hybridization studies showed that strain $\mathrm{HSM} \# 10^{\mathrm{T}}$ represents a distinct genomic species; it shared low DNA relatedness values with the type strains of its closest phylogenetic neighbours, i.e. S. chryseus DSM $40420^{\mathrm{T}}(53.55 \pm 3.15 \%$ DNA relatedness), S. helvaticus DSM $40431^{\mathrm{T}}(38.75 \pm 2.75 \%)$, S. flavidovirens DSM $40150^{\mathrm{T}}$ $(30.7 \pm 2.90 \%)$ and S. albidochromogenes DSM $41800^{\mathrm{T}}$ $(33.9 \pm 0.10 \%)$. These values are well below the $70 \%$ DNA relatedness cut-off value recommended by Wayne et al. (1987) and it is therefore proposed that strain HSM $\# 10^{\mathrm{T}}$ represents a novel species within the genus Streptomyces. A phylogenetic tree of streptomycete strains, the type strains

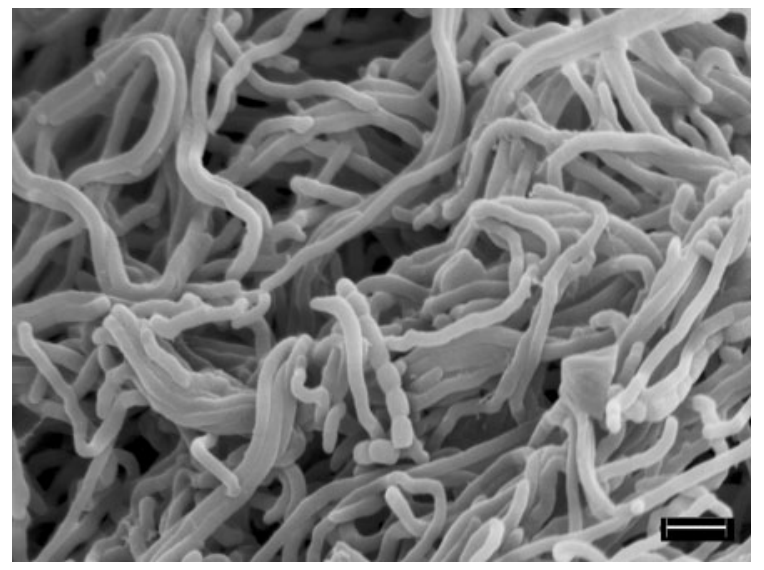

Fig. 1. Scanning electron micrograph of cells of strain $\mathrm{HSM} \# 10^{\top}$ grown on ISP 4 agar at $22{ }^{\circ} \mathrm{C}$ for 21 days. The straight spore chain morphology and smooth spores are clearly visible. Bar, $2 \mu \mathrm{m}$. 


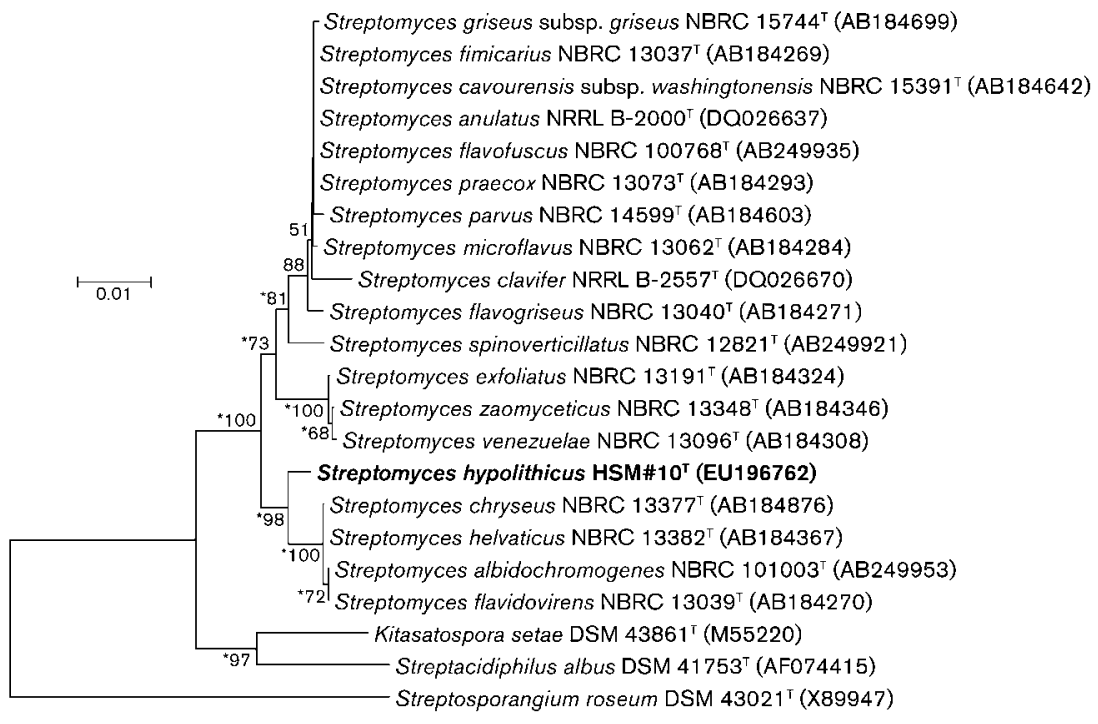

Fig. 2. Unrooted phylogenetic tree based on 16S rRNA gene sequences obtained by the neighbour-joining method showing the position of strain $\mathrm{HSM} \# 10^{\top}$ among its phylogenetic neighbours and representatives of the other genera belonging to the family Streptomycetaceae. The sequence of Streptosporangium roseum DSM 43021 was used as an outgroup. All sequences were edited to the longest common region (1460 bp). GenBank sequence accession numbers are given in parentheses. Numbers at nodes show bootstrap values (\%). Asterisks indicate clades that were conserved when the neighbour-joining, minimum evolution and maximum-parsimony methods were used to construct the phylogenetic tree. of the type species of the genera Kitasatospora and Streptacidiphilus and strain HSM $\# 10^{\mathrm{T}}$ (Fig. 2) showed that strain HSM $\# 10^{\mathrm{T}}$ clustered with members of the genus Streptomyces.

Phenotypic characteristics of strain $\mathrm{HSM} \# 10^{\mathrm{T}}$ and the two phylogenetically closest neighbours [S. chryseus NRRL B$12347^{\mathrm{T}}\left(=\mathrm{DSM} 40420^{\mathrm{T}}\right)$ and S. helvaticus NRRL B-12365 $\left(=\right.$ DSM $\left.\left.40431^{\mathrm{T}}\right)\right]$ are shown in Table 1 and Supplementary Table S1 (available in IJSEM Online). Additional physiological characteristics are given in the species description.

Based on the polyphasic taxonomic analysis described, strain HSM $\# 10^{\mathrm{T}}$ is proposed as a representative of a novel species of the genus Streptomyces, Streptomyces hypolithicus sp. nov.

Table 1. Physiological characteristics of strain $\mathrm{HSM} \# 10^{\top}$ and related strains of the genus Streptomyces

Strains: 1, strain HSM\#10 ${ }^{\mathrm{T}}$; 2, S. chryseus NRRL B- $12347^{\mathrm{T}}$; 3, S. helvaticus NRRL B-12365 ${ }^{\mathrm{T}}$. -, Negative; +, positive; w, weakly positive; Vw, very weakly positive. Unless otherwise indicated, data were obtained in this study. All three strains show smooth spore surfaces and show cream substrate mycelium when grown on ISP 4 medium.

\begin{tabular}{|c|c|c|c|}
\hline Characteristic & 1 & 2 & 3 \\
\hline Spore chain morphology & Straight & Spirals ${ }^{*}$ & Spirals/straight to flexuous ${ }^{\star}$ \\
\hline Aerial mycelium (ISP 4) & Off-white & White & White \\
\hline Growth at $37{ }^{\circ} \mathrm{C}$ & - & VW & vw \\
\hline \multicolumn{4}{|l|}{ Growth in the presence of: } \\
\hline $0.1 \%$ 2-Phenylethanol & - & + & VW \\
\hline $0.3 \%$ 2-Phenylethanol & - & $\mathrm{VW}$ & - \\
\hline \multicolumn{4}{|l|}{ Degradation of: } \\
\hline Allantoin & - & - & vW \\
\hline L-Tyrosine & - & + & - \\
\hline Xanthine & - & vw & - \\
\hline \multicolumn{4}{|c|}{ Sole carbon source utilization } \\
\hline$(+)$-L-Arabinose & - & - & W \\
\hline Fructose & - & $\mathrm{W}$ & - \\
\hline$(+)$-D-Galactose & + & + & $\mathrm{W}$ \\
\hline (-)-D-Mannitol & - & w & - \\
\hline Raffinose & - & $\mathrm{W}$ & - \\
\hline Salicin & $\mathrm{W}$ & + & - \\
\hline Sucrose & - & $\mathrm{W}$ & - \\
\hline$(+)$-D-Xylose & - & + & W \\
\hline
\end{tabular}

${ }^{\star}$ Data from Locci (1989). 


\section{Description of Streptomyces hypolithicus sp. nov.}

Streptomyces hypolithicus (hy.po.li'thi.cus. N.L. masc. adj. hypolithicus belonging to a hypolith community).

Good growth occurs on Czapek solution agar (produces white substrate and aerial mycelia); no growth is observed on Middlebrook 7H9 agar. Good growth is observed on ISP 2 , but no sporulation is observed after 14 days of growth. Very good growth is observed on ISP 4 with cream substrate and off-white aerial mycelia. No diffusible pigments are produced on ISP 5, but good growth with beige substrate and sparse white aerial mycelia is observed. No melanin production is detected on ISP 6 or ISP 7 after 14 days of growth. Very good growth on ISP 7 . Very weak growth is observed in the presence of $3 \% \mathrm{NaCl}$ and $0.1 \%$ phenol, but no growth is observed in the presence of $5 \% \mathrm{NaCl}, 0.0001 \%$ crystal violet, $0.1 \%$ 2-phenylethanol or $0.01 \% \mathrm{NaN}_{3}$. Growth is observed in the presence of penicillin G (10 IU $\left.\mathrm{ml}^{-1}\right)$, but not in the presence of cephaloridine $(100 \mu \mathrm{g}$ $\left.\mathrm{ml}^{-1}\right)$, lincomycin $\left(100 \mu \mathrm{g} \mathrm{ml}^{-1}\right)$, neomycin $\left(50 \mu \mathrm{g} \mathrm{ml}^{-1}\right)$, rifampicin $\left(50 \mu \mathrm{g} \mathrm{ml}^{-1}\right)$ or streptomycin $\left(100 \mu \mathrm{g} \mathrm{ml}^{-1}\right)$. Growth occurs at $22{ }^{\circ} \mathrm{C}$, with very weak growth at $30{ }^{\circ} \mathrm{C}$; no growth is observed at $37^{\circ} \mathrm{C}$ or at $\mathrm{pH} 4.3$. L-Arginine, Lasparagine, potassium nitrate, $\mathrm{L}$-serine and L-threonine are utilized as sole nitrogen sources; L-histidine, L-4-hydroxyproline, L-phenylalanine and L-valine are utilized weakly, but DL- $\alpha$-amino- $n$-butyric acid, L-cysteine and L-methionine are not utilized. Uses glucose and (+)-D-galactose as sole carbon sources (with weak growth on salicin), but does not utilize (+)-L-arabinose, (-)-D-fructose, myo-inositol, (-)D-mannitol, raffinose, sucrose or $(+)$-D-xylose. Degrades adenine, arbutin, casein, aesculin, gelatin and hypoxanthine, but not allantoin, cellulose, guanine, starch, tyrosine, urea, xanthine or xylan.

The type strain is strain $\mathrm{HSM} \# 10^{\mathrm{T}}$ (=DSM $41950^{\mathrm{T}}$ $=$ NRRL B-24669 ${ }^{\mathrm{T}}$ ), isolated from hypolithic community samples collected from the base of translucent quartz rocks in Miers Valley in the McMurdo Dry Valleys region of eastern Antarctica.

\section{Acknowledgements}

Our thanks to Di James for DNA sequencing and Miranda Waldron of the Electron Microscope Unit, University of Cape Town (UCT), for help with scanning electron microscopy, to Professor Dr Hans G. Trüper for assistance with Latin in deriving the specific epithet for strain HSM\# $10^{\mathrm{T}}$ and to Dr David Labeda for the NRRL strains used in this study. M.L.R.-H. holds a Claude Leon Foundation Postdoctoral Fellowship and J. R. holds a grant-holder linked bursary from the National Research Foundation of South Africa (NRF) and funding from UCT. S. G. B. is funded by the NRF.

\section{References}

Altschul, S. F., Madden, T. L., Schäffer, A. A., Zhang, J., Zhang, Z., Miller, W. \& Lipman, D. J. (1997). Gapped BLAST and PSI-BLAST: a new generation of protein database search programs. Nucleic Acids Res 25, 3389-3402.

Atlas, R. M. (2004). Handbook of Microbiological Media, 3rd edn. Edited by L. C. Parks. Boca Raton, FL: CRC Press.

Cashion, P., Holder-Franklin, M. A., McCully, J. \& Franklin, M. (1977). A rapid method for the base ratio determination of bacterial DNA. Anal Biochem 81, 461-466.

Chun, J., Lee, J.-H., Jung, Y., Kim, M., Kim, S., Kim, B. K. \& Lim, Y.-W. (2007). EzTaxon: a web-based tool for the identification of prokaryotes based on $16 \mathrm{~S}$ ribosomal RNA gene sequences. Int J Syst Evol Microbiol 57, 2259-2261.

Cockell, C. S. \& Stokes, M. D. (2004). Ecology: widespread colonization by polar hypoliths. Nature 431, 414.

Cook, A. E. \& Meyers, P. R. (2003). Rapid identification of filamentous actinomycetes to the genus level using genus-specific 16S rRNA gene restriction fragment patterns. Int J Syst Evol Microbiol 53, 1907-1915.

De Ley, J., Cattoir, H. \& Reynaerts, A. (1970). The quantitative measurement of DNA hybridization from renaturation rates. Eur $J$ Biochem 12, 133-142.

Hasegawa, T., Takizawa, M. \& Tanida, S. (1983). A rapid analysis for chemical grouping of aerobic actinomycetes. J Gen Appl Microbiol 29, 319-322.

Huß, V. A. R., Festl, H. \& Schleifer, K. H. (1983). Studies on the spectrophotometric determination of DNA hybridization from renaturation rates. Syst Appl Microbiol 4, 184-192.

Keswani, J. \& Whitman, W. B. (2001). Relationship of $16 \mathrm{~S}$ rRNA sequence similarity to DNA hybridization in prokaryotes. Int J Syst Evol Microbiol 51, 667-678.

Kumar, S., Tamura, K. \& Nei, M. (2004). MEGA3: integrated software for molecular evolutionary genetics analysis and sequence alignment. Brief Bioinform 5, 150-163.

Lechevalier, M. P. \& Lechevalier, H. A. (1970). Chemical composition as a criterion in the classification of aerobic actinomycetes. Int J Syst Bacteriol 20, 435-443.

Locci, R. (1989). Streptomyces and related genera. In Bergey's Manual of Systematic Bacteriology, vol. 4, pp. 2451-2508. Edited by S. T. Williams, M. E. Sharpe \& J. G. Holt. Baltimore: Williams \& Wilkins.

Saitou, N. \& Nei, M. (1987). The neighbor-joining method: a new method for reconstructing phylogenetic trees. Mol Biol Evol 4, 406425.

Shirling, E. B. \& Gottlieb, D. (1966). Methods for characterization of Streptomyces species. Int J Syst Bacteriol 16, 313-340.

Stackebrandt, E. \& Ebers, J. (2006). Taxonomic parameters revisited: tarnished gold standards. Microbiol Today 33, 152-155.

Takahashi, K. \& Nei, M. (2000). Efficiencies of fast algorithms of phylogenetic inference under the criteria of maximum parsimony, minimum evolution, and maximum likelihood when a large number of sequences are used. Mol Biol Evol 17, 1251-1258.

Thomas, D. N. (2005). Photosynthetic microbes in freezing deserts. Trends Microbiol 13, 87-88.

Wayne, L. G., Brenner, D. J., Colwell, R. R., Grimont, P. A. D., Kandler, O., Krichevsky, M. I., Moore, L. H., Moore, W. E. C., Murray, R. G. E. \& other authors (1987). International Committee on Systematic Bacteriology. Report of the ad hoc committee on reconciliation of approaches to bacterial systematics. Int $J$ Syst Bacteriol 37, 463-464. 